\title{
Fluid chemistry of the Theistareykir geothermal field, NE Iceland
}

\author{
DEIRDRE E. CLARK ${ }^{1}$, FINNBOGI ÓSKARSSON ${ }^{1}$, \\ FLORIAN EICHINGER ${ }^{2}$, JOY IANNOTTA ${ }^{2}$, ANDREJ \\ VOROPAEV ${ }^{2}$, STEINDÓR NIELSSON ${ }^{1}$ AND ÁSGERĐUR K. \\ SIGURĐARDÓTTIR ${ }^{3}$ \\ ${ }^{1}$ Iceland GeoSurvey \\ ${ }^{2}$ Hydroisotop GmbH \\ ${ }^{3}$ Landsvirkjun \\ Presenting Author: deirdre.clark@isor.is
}

Iceland has been a world leader in geothermal utilization, an important alternative sub-surface energy source. The most recent geothermal field developed for energy production is the Theistareykir geothermal field, which lies in in the Northern Volcanic Zone in NE-Iceland. Based on the first set of high temperature wells drilled in 2002 to 2011, Óskarsson et al. [1] determined a reservoir temperature range of $270-290{ }^{\circ} \mathrm{C}$ although the bedrock temperature exceeds $300{ }^{\circ} \mathrm{C}$. Additional production wells have been drilled since then and the power plant brought online in 2017 with an installed capacity of 90 MW.

Geothermal fluids were collected from seven high temperature geothermal wells and two re-injection wells for major and minor elemental analysis to further characterize the field's deep fluid chemistry. Stable water, carbon and sulfur isotopes were also collected and analysed to evaluate the fluid's sources. This research will build upon previous geochemical and isotopic studies [1-3] with the aim to assess exploitation-related changes to the Theistareykir geothermal reservoir and the conceptual model.

\section{Acknowledgments}

This study was done in the framework of the REFLECT project which has received funding from the European Union's Horizon 2020 research and innovation programme under grant agreement No. 850626.

References

[1] Óskarsson, Ármannsson, Ólafsson, Sveinbjörnsdóttir \& Markússon (2013), Procedia Earth and Planetary Science 7, 644 $-647$.

[2] Saby, Piniti, van Hinsberg, Gautason, Sigurðardóttir, Casto, Hall, Óskarsson, Rocher, Hélie \& Méjean (2020), Journal of Volcanology and Geothermal Research 405, 107062.

[3] Sveinbjornsdottir, Ármannsson, Ólafsson, Óskarsson, Markússon \& Magnusdottir (2013), Procedia Earth and Planetary Science 7, 822 - 825. 